\title{
Soil color analysis for statistically estimating total carbon, total nitrogen and active iron contents in Japanese agricultural soils
}

\section{$\operatorname{AUTHOR(S):~}$}

Moritsuka, Naoki; Matsuoka, Kaori; Katsura, Keisuke; Sano, Shuji; Yanai, Junta

\section{CITATION:}

Moritsuka, Naoki ... [et al]. Soil color analysis for statistically estimating total carbon, total nitrogen and active iron contents in Japanese agricultural soils. Soil Science and Plant Nutrition 2014, 60(4): 475-485

\section{ISSUE DATE:}

2014-06-17

URL:

http://hdl.handle.net/2433/198800

\section{RIGHT:}

This is an Accepted Manuscript of an article published by Taylor \& Francis in "Soil Science and Plant Nutrition" on 17 Jun 2014, available online: http://www.tandfonline.com/10.1080/00380768.2014.906295:; この論文は出版社版でありま せん。引用の際には出版社版をご確認ざ利用ください。; This is not the published version. Please cite only the published version. 


\title{
Soil color analysis for statistically estimating total carbon, total nitrogen and active iron contents in Japanese agricultural soils
}

\author{
Naoki Moritsuka ${ }^{1}$, Kaori Matsuoka ${ }^{1,2}$, Keisuke Katsura ${ }^{1}$, Shuji Sano ${ }^{3}$, and Junta Yanai ${ }^{4}$ \\ ${ }^{1}$ Graduate School of Agriculture, Kyoto University, Kyoto 606-8502, Japan \\ 2 NARO Institute of Fruit Tree Science, Tsukuba 305-8605, Japan \\ ${ }^{3}$ Research Institute of Environment, Agriculture and Fisheries, Osaka Prefecture, Osaka 583-0862, \\ Japan \\ ${ }^{4}$ Graduate School of Life and Environmental Sciences, Kyoto Prefectural University, Kyoto \\ 606-8522, Japan
}

\begin{abstract}
Soil color originates mainly from organic matter, iron mineralogy, and moisture content. We aimed to find a suitable method to measure soil color sensitively and to evaluate the extent to which the color parameters can be useful for statistically estimating total carbon, total nitrogen and active iron contents in Japanese agricultural soils. A soil color reader (SPAD-503) was applied to two sample sets; 1) 100 surface soils collected throughout from a 0.5-ha paddy field (field scale) and 2) 147 surface soils collected from agricultural fields in Japan (national scale). For the analysis with this instrument, about two grams of air-dried, finely-ground samples were packed firmly in a plastic cell, and their colors appeared on windows in both sides of the cell were measured. A CIE 1976 (L*, a*, $b^{*}$ ) color space was used for color description. For the field-scale samples, the values of the coefficient of variation were around $15 \%$ for total $\mathrm{C}$, total $\mathrm{N}$ and acid oxalate extractable $\mathrm{Fe}\left(\mathrm{Fe}_{\mathrm{o}}\right)$. The $\mathrm{L}^{*}$ value (lightness) was negatively correlated with the content of total $\mathrm{C}$ and total $\mathrm{N}\left(\mathrm{R}^{2}=\right.$ $0.18^{* *}$ and $0.26^{* *}$, respectively), and the $\mathrm{b}^{*}$ value (yellowness) was positively correlated with the $\mathrm{Fe}_{\mathrm{o}}$ content $\left(\mathrm{R}^{2}=0.59^{* *}\right)$. For the national-scale samples, the values of the coefficient of variation were around $60 \%$ for total $\mathrm{C}$, total $\mathrm{N}$ and $\mathrm{Fe}_{\mathrm{o}}$. The $\mathrm{L}^{*}$ value was negatively correlated with the content of total $\mathrm{C}$ and total $\mathrm{N}\left(\mathrm{R}^{2}=0.70^{* *}\right.$ and $0.59^{* *}$, respectively), but the $\mathrm{b}^{*}$ value was not correlated with the content of $\mathrm{Fe}_{o}\left(\mathrm{R}^{2}=0.00\right)$. When the analysis was limited to 65 samples frequently used for paddy fields, the $b^{*}$ value was positively correlated with the $\mathrm{Fe}_{0}$ content $\left(\mathrm{R}^{2}=\right.$ $0.52^{* *}$ ). In conclusion, the proposed method enabled to measure soil color sensitively with a small sample size. The $\mathrm{L}^{*}$ and $\mathrm{b}^{*}$ values obtained can be useful for rapid estimation of total $\mathrm{C}$, total $\mathrm{N}$ and $\mathrm{Fe}_{\mathrm{o}}$ contents in agricultural surface soils in Japan.
\end{abstract}

Key words: Active iron, Japanese agricultural soils, Organic matter, Paddy field, Soil color reader (SPAD-503) 


\section{INTRODUCTION}

Soil color has been used as one of the key attributes to differentiate horizons in a profile and to classify soil types in a region. Routine measurement of soil color has often been accomplished in the field by visually comparing a soil sample with the chips of standard color charts. The Munsell color charts based on the Munsell color system are the most familiar to soil scientists (Munsell 1905). In Japan, for example, the negative correlation between the content of organic matter and the Munsell value has been used for in-situ estimation of organic matter level in soils especially Andosols (Japanese Society of Pedology 1997). Due to several psychophysical and physical factors, however, substantial errors are involved in this visual and subjective method (Torrent and Barrón 1993).

More sensitive measurement of soil color in the laboratory is possible by using colorimeters, provided that the white standards and soil samples are carefully prepared (Torrent and Barrón, 1993; Nishiyama et al. 2011; Sawada et al. 2013; Liles et al. 2013). Digital cameras and spectrometers have also been used for measurement of soil color (Viscarra Rossel et al. 2006; Viscarra Rossel et al. 2008; Doi et al. 2010). A soil color reader (SPAD-503, Konica Minolta Optics, Inc.) introduced for soil analysis in 1996 is one of the tristimulus reflectance colorimeters.

However, the reports on the use of the soil color reader or other colorimeters in the laboratory are limited in number. Most of them have dealt with a wide variation of soil color at a regional scale (Yang et al. 2001; Yamaki and Anzai 2001; Konen et al. 2003; Wills et al. 2007; Liles et al. 2013). This may be due to the following reasons; 1 ) a portable SPAD-503 is designed for use in the field and a standard procedure for the use in the laboratory is not well established, and 2) the analytical performance, i.e., sensitivity and reproducibility, of the instrument is not known and consequently the importance of the analysis and the obtained data is not fully understood. Especially unknown is whether the colorimeter can be sensitive enough to detect soil color variations in an individual field with an area of less than 1 ha, which is a normal size of a field in Japan and other highly populated countries in Asia.

From an agronomic viewpoint, the importance of soil color analysis relates to the fact that the soil properties like organic matter, iron mineralogy and moisture content are strongly related to soil color (Post et al. 1993). Organic matter in soil is closely linked with the content of total nitrogen, and it will influence the availability of nitrogen to plants. On the other hand, active iron in soil will affect the availability of iron to plants, the degree of phosphorus adsorption and the decrease of the redox potential after flooding. Analysis of soil color parameters by using a colorimeter in the laboratory can be a quick approach for estimating their related properties. Furthermore, soil color analysis can be helpful at smaller scales than previously reported. For example, it can be useful for diminishing within-field heterogeneity of organic matter level in the surface layer by site-specific manure management, or for diminishing within-field heterogeneity of crop growth by site-specific application of $\mathrm{N}$ or Fe fertilizer, provided that the above mentioned problems are solved. 
Based on these backgrounds, we applied the soil color reader (SPAD-503) to two sample sets: one collected from a single paddy field (field-scale) and the other collected throughout from Japan (national-scale). In this paper, we present a suitable method to measure soil color sensitively and then show the extent to which the color parameters can be useful for statistically estimating total carbon, total nitrogen and active iron contents in Japanese agricultural soils.

\section{MATERIALS AND METHODS}

\section{Soil samples}

Samples collected at field and national scales were subjected to analyses.

For the field-scale samples, 100 samples were collected from the plow layer of a paddy field. The sampling was carried out at an experimental paddy field of Kyoto University, located at Takatsuki city, Osaka prefecture in Japan. The area of the field examined was 0.5 ha $(50 \times 100 \mathrm{~m})$ with an almost flat topography (Yanai et al. 2001). The soil in this field was classified as Typic Fluvaquent (Soil Survey Staff 2010). The general properties of the soil and their spatial variations are described in Moritsuka et al. (2004). Soil samples were collected on the 1st and 2nd of May, 2012 before puddling and transplanting of seedlings of rice (Oryza sativa L. var. Hinohikari) in the same way as the first author did in 2002 (Moritsuka et al. 2004). To sample soils throughout from the field, the field was divided into hundred plots with an area of $5 \times 10 \mathrm{~m}$. In each plot, a soil sample consisting of 5 sub-samples was taken from the surface $(<15 \mathrm{~cm})$ within a $2 \mathrm{~m}$ circular area from the center of the plot.

For the national-scale samples, on the other hand, 147 samples were collected during 1998-1999 by the co-authors (Sano and Yanai) from the plow layer $(<15 \mathrm{~cm}$ ) of agricultural fields in Japan; 80 samples from paddy fields and 67 samples from upland fields. Soil samples include various kinds of soils, roughly corresponding to the distribution area of soil groups on a nationwide scale (Sano et al. 2004). In this paper, these soils were classified into the following three groups; 1) soils frequently used for paddy fields which are referred to as paddy soils hereafter (65 samples including soil types classified as Lowland Paddy soils, Gley Lowland soils and Gray Lowland soils), 2) Andosols (43 samples including soil types classified as Wet Andosols, Non-allophanic Andosols and Andosols), and 3) other 39 samples including various soil types such as Brown Lowland soils ( $n=12)$, Yellow soils ( $\mathrm{n}=9$ ) and Peat soils ( $\mathrm{n}=7$ ) (Sano et al. 2004). It should be noted that this classification does not reflect the land use (paddy or upland fields) at the time of sampling and that 80 soil samples collected from paddy fields were composed of 60 paddy soils, 11 Andosols and 9 other soils.

The samples were air-dried and 2-mm sieved before analyses. For color analysis, further grinding of the samples with a tungsten mortar was carried out for increasing the reproducibility described in the following section. For the field-scale samples with a much smaller color variation than the national-scale samples, the grinding procedure was standardized as follows; a $2.00 \mathrm{~g}$ of air-dried, 
2-mm sieved soil was placed in a tungsten mortar and ground by hand for 3 minutes. For the national-scale samples, the grinding procedure was not strictly fixed; about $5 \mathrm{~g}$ of air-dried, 2-mm sieved sample was placed in a tungsten mortar and ground for about 5 minutes

\section{Soil color analysis by SPAD-503}

The soil color reader (SPAD-503) is a tristimulus colorimeter, which is equipped with a gas-filled tungsten lamp for a D65 standard light shed to the object at an angle of 8 degrees, an integrating sphere to provide a diffuse light, a light trap to exclude specular reflectance and six silicon photocells to receive the diffuse light of the object and measure the tristimulus values of the light. The cost of SPAD-503 including accessories such as a protective glass cover and a white calibration plate is about 3000 US dollars.

The instrument can describe soil color in two modes; Munsell color system and CIE 1976 (L*, a*, $b^{*}$ ) color space (CIELAB). The Munsell color system, which is familiar to soil scientists, is based on three attributes; hue, value, and chroma. On the other hand, the CIELAB color space recognizes color in a three-dimensional space, where the $\mathrm{L}^{*}, \mathrm{a}^{*}$, and $\mathrm{b}^{*}$ axes represent whiteness-blackness (lightness-darkness), redness-greenness and yellowness-blueness, respectively. The $L^{*}$ value ranges from 0 (black) to 100 (white), whereas positive $a^{*}$ and $b^{*}$ values indicate the degree of redness and yellowness, respectively. Schematic diagrams of color space models are described by Viscarra Rossel et al. (2006). By this instrument, soil color is firstly measured by the CIELAB color space, and secondly a Munsell color chart with the least color difference is displayed.

Soil color analyses except for preliminary trials were carried out on the 16th of December and the 15th of October in 2012 for field-scale and national-scale samples, respectively. Since any color difference among the field-scale samples could not be detected by the soil color reader using the Munsell color system (i.e., the samples were recognized as 10YR6/2 by the instrument), we selected the more sensitive CIELAB color space for the analysis. From the color parameters obtained from the CIELAB color space, two additional parameters (chroma and hue angle) were also calculated by the following formula (Viscarra Rossel et al. 2006); chroma $\left(\mathrm{C}^{*}\right)=\left(\mathrm{a}^{* 2}+\mathrm{b}^{* 2}\right)^{1 / 2}$, hue angle $(\mathrm{h})=$ $\left(\tan b^{*} / a^{*}\right)^{-1}$ (degree). Furthermore, the $L^{*}$ values of CIELAB color space were converted into Munsell values (lightness) for the national scale samples by using a chart for conversion presented by Kitamura (1993), and the extent to which Munsell value is useful for estimating organic matter level in soils was evaluated.

Before analysis, the soil color reader was attached with a CR-A79 protective glass (blue plate glass) cover and calibrated with a CR-A74 white calibration plate (opal glass) according to the user manual for SPAD-503. For soil color analysis, $2.00 \mathrm{~g}$ of a sample for field-scale samples or about $2 \mathrm{~g}$ of a sample for national-scale samples was placed in a disposable polystyrene cell (W10 $\times$ D10 $\times$ H43 mm internal size; Sanplatec Co., Ltd., Osaka, Japan) with transparent windows on both sides. 
The cell is conventionally used for the colorimetric analysis of liquid samples by spectrophotometer. Then, the cell was gently tapped on a working table until the soil was packed firmly and the air space appeared on a cell window was removed completely. The instrument was placed horizontally on a working table, and the protective glass cover was removed. Color of a soil on both windows of the cell was measured (Figure 1) and the obtained values were averaged. During the measurement, the white calibration plate was measured every ten samples to check the accuracy of analysis. Because it was difficult to wet the soil in a cell homogeneously without an occasional formation of a horizontal crack, only the color of the air-dried samples was measured.

\section{Analysis of soil chemical properties affecting soil color}

In addition to soil color, total $\mathrm{C}$, total $\mathrm{N}$ and acid oxalate extractable $\mathrm{Fe}\left(\mathrm{Fe}_{0}\right)$ contents were determined as the properties affecting both color and fertility of soils. Total $\mathrm{C}$ and $\mathrm{N}$ were measured by the dry combustion method using the finely ground samples. For the national scale samples, the content of organic matter was calculated by multiplying total C content by a factor of 1.724 (Nelson and Sommers 1996). $\mathrm{Fe}_{\mathrm{o}}$ was measured by ICP emission spectrometer after extraction of the 2-mm sieved samples with $0.2 \mathrm{~mol} \mathrm{~L}^{-1}$ ammonium oxalate solution at pH 3.0 (Loeppert and Inskeep, 1996).

\section{Statistical Analysis}

Descriptive statistics, correlation analysis and regression analysis of the above data were carried out using Microsoft Excel 2010 for Windows.

\section{RESULTS AND DISCUSSION}

\section{Establishment of procedures for soil color analysis by SPAD-503}

In this section, the effects of grinding and packing of soil samples on color parameters measured by SPAD-503 are described by referring to the preliminary attempts for method establishment.

The manner in which a soil sample is prepared markedly affects color values determined (Torrent and Barrón 1993). In a preliminary experiment, the following preparations were tested for the field-scale samples: 1) untreated (air-dried and 2-mm sieved) and 2) finely ground with a tungsten mortar. The first treatment is the sample preparation for routine analyses, and the second treatment was carried out for further homogenization of the sample. Then, it was found that color values obtained from a finely ground sample were more reproducible than those from a 2-mm sieved sample (Figure 2). The low reproducibility for a 2-mm sieved sample was probably due to a small area of the measurement (about $0.5 \mathrm{~cm}^{2}$ with a diameter of $0.8 \mathrm{~cm}$ ) by the soil color reader and also due to the incomplete contact between soil samples and an observation window creating an erratic shade and decreasing the lightness of color (Figure 2).

Thus, sample homogenization by grinding was found to be necessary for our field-scale samples 
with a narrow color variation. Changing the period of grinding of $2 \mathrm{~g}$ soil from 1 to 5 minutes increased the color parameters. On the average, the lightness ( $\mathrm{L}^{*}$ value) and yellowness ( $b^{*}$ value) increased by the units of 2.7 and 0.55 , respectively, when two of the field-scale samples were analyzed. But these increases were much less than those previously reported using a ball mill (Torrent and Barrón, 1993) or using an agate mortar for 10 minutes (Inoue et al. 2006). This is probably because soil grinding by hand with a tungsten mortar for a few minutes was much milder than that with a ball mill and an agate mortar for a longer period. For one of the field-scale samples, the grinding for 3 minutes did not change the particle size distribution except for transformation of a coarse sand fraction to a fine sand fraction (i.e., coarse sand, fine sand, silt and clay percentages at 14, 24, 34 and 28\% before grinding and 3, 33, 35 and 29\% after grinding, respectively).

Sample surface roughness during color measurement is another issue to be solved to increase the reproducibility (Torrent and Barrón 1993). For example, Liles et al. (2013) tried to diminish surface roughness and heterogeneous particle distribution for 2-mm sieved soils by brushing the soil surface lightly prior to color measurement. In this study, we packed the samples firmly in a plastic cell to ensure a perfectly flat surface for measurement. Once the samples are packed and ready for analysis, color measurement takes less than one minute per sample with a duplicate measurement. However, transparent materials such as a protective cover and a plastic cell placed between the sensor of the colorimeter and a sample may affect the color measurements (Barrett 2002). So the possible error originating from using different transparent materials during calibration and sample measurement was evaluated.

After normal calibration with a white calibration plate and a protective glass cover, barium sulfate powder for white standard DIN 5033 (Merck KGaA) was packed firmly in a plastic cell or a quartz cell (S10-UV-10, GL Sciences Inc., Japan) and the color was measured four times without the protective cover in the same way as we did for soil samples. The reflectance values of the barium sulfate white standard DIN 5033 is known to be about $98 \%$ for the 400 to $700 \mathrm{~nm}$ range (Torrent and Barrón 1993). Then the average $L^{*}, a^{*}$ and $b^{*}$ values were 98.4, 0.4 and 0.4, respectively, for the plastic cell and 100.4, 0.1, 0.0, respectively, for the quartz cell. The lower $\mathrm{L}^{*}$ and higher $\mathrm{a}^{*}$ and $\mathrm{b}^{*}$ values for the white standard packed in the plastic cell suggested slight color absorbance by polystyrene, which amounted to at most 2 units for the $\mathrm{L}^{*}$ value and 0.4 units for the $\mathrm{a}^{*}$ and $\mathrm{b}^{*}$ values. The $L^{*}$ value of the white standard measured with the plastic cell (98.4) was close to the previously reported value, suggesting that the protective glass cover and the plastic cell displayed a similar effect on the color absorbance and measurements.

\section{Variation of soil color parameters and their related properties}

The descriptive statistics of soil color parameters and their related properties are listed in Table 1. In general, the values of the coefficient of variation (CV) for total $\mathrm{C}$, total $\mathrm{N}$ and $\mathrm{Fe}_{\mathrm{o}}$ contents were 
larger than those for soil color parameters.

Variations of soil color became apparent even at a field scale, although the difference was not detectable by the soil color reader using the Munsell color system and the color was classified as 10YR 6/2. Compared with the soil color parameters of paddy soils at a national scale, the soil color collected from the paddy field was characterized by lower $\mathrm{L}^{*}, \mathrm{a}^{*}, \mathrm{~b}^{*}$ and $\mathrm{C}^{*}$ values.

Among the soil types at a national scale, Andosols were characterized by a lower $\mathrm{L}^{*}$ value and higher contents of total $\mathrm{C}$, total $\mathrm{N}$ and $\mathrm{Fe}_{\mathrm{o}}$. Paddy soils were characterized by a low $\mathrm{CV}$ value for $\mathrm{L}^{*}$ value. The highest $\mathrm{L}^{*}, \mathrm{a}^{*}, \mathrm{~b}^{*}$ and $\mathrm{C}^{*}$ values were recorded from the same sample; a Yellow soil collected from Okinawa Prefecture (southernmost prefecture in Japan), whose total C content was the lowest.

Color parameters of the national-scale samples were measured more than a decade after sampling. We are not sure if colors of these samples have changed during a long storage. For the field-scale samples, however, the samples collected from the same paddy field on the 30th of April in 2002 by the same way (Moritsuka et al. 2004) and measured on the 16th of December in 2012 showed color parameters almost identical to those in Table 1 . The average $\mathrm{L}^{*}, \mathrm{a}^{*}$ and $\mathrm{b}^{*}$ values were 57.7, 3.4 and 11.6, respectively. This implies that color barely changed from a half year to a decade after sampling of the field-scale samples.

\section{Relationship among soil color parameters and their related properties}

The correlation matrix among the soil color parameters and their related properties are shown in Tables 2 and 3. Among the color parameters, significant correlations were observed for both field and national scale samples. This indicates that color parameters were not independent with each other, which agrees with previous reports showing significantly positive correlations among the L*, $a^{*}$ and b* values for cultivated and uncultivated soils in France (Viscarra Rossel et al. 2008).

Due to the correlations among the color parameters, total $\mathrm{C}$ and $\mathrm{N}$ contents were negatively correlated with the $\mathrm{L}^{*}, \mathrm{~b}^{*}, \mathrm{C}^{*}$ and $\mathrm{h}$ values for both sample sets $(\mathrm{p}<0.01)$. On the other hand, the $\mathrm{Fe}_{\mathrm{o}}$ content was positively correlated with all color parameters for field-scale samples, although it was not positively correlated with any color parameters and even negatively correlated with the $L^{*}$ and $h$ values for national-scale samples.

The relationships observed between soil color parameters and their related properties are depicted in Figures 3 and 4. Among the significant relationships observed, those seemed useful for estimating soil properties were selected. At a field scale, the $L^{*}$ value (lightness) was negatively correlated with the content of total $\mathrm{C}$ and total $\mathrm{N}(\mathrm{p}<0.01)$, and the $\mathrm{b}^{*}$ value (yellowness) was positively correlated with the $\mathrm{Fe}_{o}$ content $(\mathrm{p}<0.01)$. At a national scale, on the other hand, the $\mathrm{L}^{*}$ value was negatively correlated with the content of total $\mathrm{C}$ and $\mathrm{N}(\mathrm{p}<0.01)$. The regression equation for total $\mathrm{C}$ obtained from all soils $(y=-2.32 x+159)$ was similar to that obtained from the field-scale samples. When the 
analysis was limited to paddy soils, however, the correlation between the $\mathrm{L}^{*}$ value and total C and $\mathrm{N}$ became weaker, probably because of a small variation of the $\mathrm{L}^{*}$ value for the paddy soils (Table 1 ). On the other hand, the $\mathrm{b}^{*}$ value was not correlated with the content of $\mathrm{Fe}_{0}$. When the analysis was limited to paddy soils or Andosols, however, the $b^{*}$ value was positively correlated with the $\mathrm{Fe}_{\mathrm{o}}$ content $(\mathrm{p}<0.01)$. Again the regression equation for paddy soils $(y=0.86 \mathrm{x}-5.52)$ was similar to that obtained from the field-scale samples.

For national scale samples, the Munsell value converted from the $\mathrm{L}^{*}$ value provided 8 classes ranging from 3 to 6.5 when the Munsell value was recorded by 0.5 units (Figure 5). The Munsell value was negatively correlated with the content of organic matter calculated from total C content. This suggests that analysis of Munsell value of air-dry, finely-ground soils in the laboratory using the Munsell color charts can be useful for estimating organic matter level when we analyze soil samples with a wide range of soil color. The broken line in the figure, which is an approximate guide used for in-situ estimation of organic matter in Andosols in Japan, showed much smaller intercepts with $\mathrm{x}$ and $y$ axes than the regression equation obtained from our study, probably due to the effect of moisture and surface roughness on the decrease of soil lightness.

\section{Estimation of carbon, nitrogen and active iron by soil color analysis}

Organic matter and iron-bearing minerals are the dominant pigments in air-dry soils except for soils abundant in salts and manganese oxides. The question is to what extent soil color parameters can estimate these two properties. Organic matter in soil is closely linked with the content of total $\mathrm{N}$ except for soils abundant in inorganic $\mathrm{N}$ or fixed ammonium, and indirect estimation of total $\mathrm{N}$ by soil color analysis would also be feasible for most agricultural soils. In our case, most of the total $\mathrm{N}$ was composed of organic $\mathrm{N}$ for all samples except for a single Yellow soil from Okinawa Prefecture whose total $\mathrm{C}$ content and the $\mathrm{C} / \mathrm{N}$ ratio were lowest due partly to abundant fixed ammonium in the soil (Sano et al. 2004). Our results suggested that the relationships between soil color parameters and their related properties depend on the type of sample sets and sampling scales. So calibration is necessary when we try to estimate soil properties from soil color parameters. By the method described here, the sample size required for color measurement could be reduced to be two grams. The sample can be reused for the analysis of total $\mathrm{C}$ and $\mathrm{N}$ by the dry combustion method required for calibration.

As for total $\mathrm{C}$ and $\mathrm{N}$, it is widely accepted that the Munsell value or the $\mathrm{L}^{*}$ value decreases linearly or curvilinearly, as the content of organic matter increases (Schulze et al. 1993; Yang et al. 2001; Wills et al. 2007; Viscarra Rossel et al. 2008; Liles et al. 2013). In the case of semiarid soils containing a large amount of calcium carbonate, however, the carbonates can mask the influence of organic matter on lightness (Ibáñez-Asensio et al. 2013). The L* value and Munsell value were also an effective predictor for our sample sets (Figures 3-5). The humic acid fraction is responsible for 
the dark color of the soil organic matter (Schulze et al. 1993). Using a similar method for soil color measurement, Yang et al. (2001) also reported a well-fit regression equation between the $\mathrm{L}^{*}$ value and organic $\mathrm{C}$ content for 36 soils collected from the B horizon covering from the semi-humid to semi-arid area in China. The regression equation was linear (Organic $C\left(\mathrm{~g} \mathrm{~kg}^{-1}\right)=-1.16 \times \mathrm{L}^{*}+71.5$, $\mathrm{R}^{2}=0.88$ ) with a smaller $\mathrm{y}$-intercept and a gentler slope than ours (Figure 3).

In terms of the differences in the regression equations, Schulze et al. (1993) pointed out that the relationship between the organic matter content and the Munsell value for Ap horizons of Indiana soils was strongly affected by soil texture and landscape and that it is not always possible to estimate the organic matter content across a wide range of soil types and landscapes with a single equation. The term "landscape" in their paper is defined as a group of soils occurring together within the same physical field and usually receiving uniform management practices (Schulze et al. 1993). The major soil-forming factors within the landscape are topography and the texture of the parent material, whereas those across the landscapes are parent materials and vegetation. Our field-scale samples were within a single landscape by their definition, although the area of a field in Japan is much smaller than in the USA and irrigated paddy fields have a flat topography.

The influence of soil types and parent materials on the relationship between the $\mathrm{L}^{*}$ value and total C content was also demonstrated by Liles et al. (2013). They analyzed about 1900 forest soil samples collected from 0-10, 10-20, 20-30 cm depths at 16 locations around Northern California. Air-dried, 2-mm sieved samples were subjected to color measurement with a Minolta CR-400 chromameter. Then a logarithmic rather than a linear relationship between the $\mathrm{L}^{*}$ value and soil $\mathrm{C}$ was observed. The determination coefficients $\left(\mathrm{R}^{2}\right)$ for the relationship between $\log _{10}$ soil $\mathrm{C} \%$ and the $L^{*}$ value were variable with soil types and parent materials; e.g., 0.34 for all samples $(n=1884), 0.83$ for Inceptisols ( $\mathrm{n}=431), 0.6$ for Andisols ( $\mathrm{n}=101), 0.036$ for Alfisols $(\mathrm{n}=547)$ and 0.35 for Ultisols $(\mathrm{n}=805)$. In their paper, the average $\mathrm{L}^{*}$ value and total $\mathrm{C}$ content were 40 and $31.9\left(\mathrm{~g} \mathrm{~kg}^{-1}\right)$, respectively. The average $\mathrm{L}^{*}$ value was much lower than that of our national-scale samples, although total C content was similar. This may be due to different analytical conditions especially sample preparation methods besides the different characteristics of the samples analyzed.

Unlike these previous reports from the USA, a linear relationship between lightness and soil C or $\mathrm{N}$ was observed at a national scale (Figures 4 and 5). The reason for the better fitting may be related to the presence of humus-rich, dark-colored Andosols (Andisols) in Japan which extended and strengthened the linear relationship. Since our national-scale samples include various types of soils collected throughout from Japan, the regression equation obtained in the present study may work as a reference calibration curve for Japanese agricultural soils collected from the surface layer, provided that the samples are analyzed by similar procedures, i.e., analysis of soil color for air-dried, finely-ground samples using SPAD-503.

As for $\mathrm{Fe}_{\mathrm{o}}$, on the other hand, our results suggested that its estimation by soil color need to be 
done at an individual field scale or within a certain soil type, since it was difficult to obtain a general relationship between the $\mathrm{Fe}_{o}$ content and soil color across a wide range of soils. Ferrihydrite is the main component of $\mathrm{Fe}_{\mathrm{o}}$ (Parfitt and Childs, 1988). It is a poorly crystalline hydrated ferric oxide with a Munsell hue ranging from 5YR to 7.5YR and a Munsell value of 6 or less (Schwertmann 1993). The most frequent color of ferrihydrite is strong brown with an average Munsell color of 6.6YR 4.9/6.3 (Scheinost and Schwertmann 1999). All color parameters are thus affected by the presence of ferrihydrite. In the case of our national-scale samples, $\mathrm{Fe}_{\mathrm{o}}$ was positively correlated with total $\mathrm{C}$ and $\mathrm{N}$ (Table 3). So the estimation of the $\mathrm{Fe}_{\mathrm{o}}$ content from soil color can be hampered by the influence of organic matter, unless a color parameter which is least affected by organic matter is introduced. In our case, the $\mathrm{b}^{*}$ value was positively correlated with the $\mathrm{Fe}_{\mathrm{o}}$ content for paddy soils at both field and national scales and also for Andosols. This indicates that the $b^{*}$ value can be useful for these soil types collected from the surface layer of Japanese agricultural fields.

It should be noted here that the $b^{*}$ value was affected not only by $\mathrm{Fe}_{\mathrm{o}}$ but also by organic matter and less extractable Fe minerals such as goethite and hematite. Our national-scale samples and a representative field-scale sample were included in the sample set examined by Yanai et al. (2012). In their paper, 180 samples were subjected to the analysis of total contents of multiple elements. The content of total Fe was $18.9 \mathrm{~g} \mathrm{~kg}^{-1}$ for the sample collected from the same field as our field-scale sample, whereas the content was $39.9 \mathrm{~g} \mathrm{~kg}^{-1}$ on the average for their national-scale samples. Combining this information with our results in Table 1, it was suggested that, on the average, more than $70 \%$ of Fe in our samples was not extracted with an acid ammonium oxalate solution used for $\mathrm{Fe}_{0}$. For the field-scale samples, extrapolation of the regression equation between the $\mathrm{b}^{*}$ value and $\mathrm{Fe}_{\mathrm{o}}$ in Figure 3 indicated that the $\mathrm{b}^{*}$ value became positive (6.78) when $\mathrm{Fe}_{\mathrm{o}}$ was zero, which implies that the $\mathrm{b}^{*}$ value was originated from components other than $\mathrm{Fe}_{\mathrm{o}}$. This is also true of the paddy soils of our national-scale samples, whose regression equation $(y=0.86 x-5.52)$ was similar to the field-scale samples. Furthermore, all soils showing the $b^{*}$ value higher than 25 ( $n=6$, Figure 4) were either Yellow soils or Dark Red soils collected from Okinawa Prefecture. These soils were high in lightness and chroma with the average $\mathrm{L}^{*}, \mathrm{a}^{*}, \mathrm{~b}^{*}$ and $\mathrm{C}^{*}$ values of 64.0, 12.5, 31.0 and 33.5, respectively, and were low in $\mathrm{Fe}_{\mathrm{o}}$ (Figure 4) and total $\mathrm{C}\left(8.0 \mathrm{~g} \mathrm{~kg}^{-1}\right.$ on the average). This suggests that the $b^{*}$ values of these soils were originated mainly from less extractable Fe minerals.

In contrast to our results, the $\mathrm{Fe}_{o}$ content was negatively correlated with the $\mathrm{L}^{*}$ value followed by the $b^{*}$ value of the CIELAB color space, when about hundred surface soil samples collected from cultivated and uncultivated lands in France were analyzed (Viscarra Rossel et al. 2008). This is probably because the influence of $\mathrm{Fe}_{o}$ on soil color parameters may have been masked by that of organic matter due to a larger variation of organic carbon (CV 66\%) than that of $\mathrm{Fe}_{\mathrm{o}}$ (CV 33\%) and a positive correlation between organic carbon and $\mathrm{Fe}_{\mathrm{o}}(\mathrm{r}=0.64)$ for their sample set. 


\section{Conclusions}

Soil color analysis in the laboratory is an intermediate approach between visual evaluation in the field and chemical analysis in the laboratory. So it may contribute to bridging the gap between these approaches. The analytical procedures described here enabled to measure soil color sensitively with a small sample size. The measurement of soil color by a soil color reader (SPAD-503) allowed a rapid estimation of total $\mathrm{C}$, total $\mathrm{N}$ and $\mathrm{Fe}_{\mathrm{o}}$, provided that the samples were air-dried and finely ground and that the suitable color parameters were selected. The $\mathrm{L}^{*}$ and $\mathrm{b}^{*}$ values (or Munsell value) can be useful for estimating total $\mathrm{C}$, total $\mathrm{N}$ and $\mathrm{Fe}_{\mathrm{o}}$ contents in agricultural surface soils in Japan. For a better understanding of the relationship between soil color and its related properties, further investigation is necessary to evaluate the applicability of our results to a wider range of soils collected from other countries or other land uses such as forest and grassland as well as to deeper soils below the surface layer.

\section{Acknowledgement}

The authors are grateful to anonymous reviewers for valuable comments to the manuscript, the staffs of Konica Minolta, Inc. for the information of soil color reader (SPAD-503), and the staffs of Laboratory of Soil Science, Kyoto University for use of ICP emission spectrometer. This study was supported by a Grant for Environmental Research Projects, The Sumitomo Foundation (Grant no. 123167).

\section{REFERENCES}

Barrett LR 2002: Spectrophotometric color measurement in situ in well drained sandy soils. Geoderma, 108, 49-77.

Doi R, Wachrinrat C, Teejuntuk S, Sakurai K, Sahunalu P 2010: Semiquantitative color profiling of soils over a land degradation gradient in Sakaerat, Thailand. Environ. Monit. Assess., 170, 301-309.

Ibáñez-Asensio S, Marque’s-Mateu A, Moreno-Ramón H, Balasch S 2013: Statistical relationships between soil colour and soil attributes in semiarid soils. Biosyst. Eng., 116, 120-129.

Inoue Y, Onbe S, Nagaoka S, Nishiyama K 2006: Properties of volcanogenic dark red soils at the southwest of Shimabara peninsula, Japan. Pedologist, 50, 60-67 (in Japanese with English summary).

Japanese Society of Pedology 1997: A handbook for soil survey. Revised edition. p.169, Hakuyusha, Tokyo (in Japanese).

Kitamura Y 1993: Expression of wood color -Simplified method for conversion of CIELAB system into Munsell color system. Bull. For. \& For. Prod. Res. Inst., 365, 1-32 (in Japanese with English summary). 
Konen ME, Burras CL, Sandor JA 2003: Organic carbon, texture, and quantitative color measurement relationships for cultivated soils in North Central Iowa. Soil Sci. Soc. Am. J., 67, 1823-1830.

Liles GC, Beaudette DE, O'Geen AT, Horwath WR 2013: Developing predictive soil C models for soils using quantitative color measurements. Soil Sci. Soc. Am. J., 77, 2173-2181.

Loeppert RH, Inskeep WP 1996: Iron. In Methods of Soil Analysis, Part 3, Chemical Methods, SSSA Book Series No. 5, p. 639-664, Soil Science Society of America and American Society of America, Madison.

Moritsuka N, Yanai J, Umeda M, Kosaki T 2004: Spatial relationships among different forms of soil nutrients in a paddy field. Soil Sci. Plant Nutr., 50, 565-573.

Munsell AH 1905: A Color Notation: A Measured Color System, Based on the Three Qualities Hue, Value, Chroma with Illustrative Models, Charts, and a Course of Study Arranged for Teachers, p.89. G. H. Ellis Co., Boston.

Nelson DW, Sommers LE 1996: Total carbon, organic carbon, and organic matter. In Methods of Soil Analysis. Part 3. Chemical Methods. DL Sparks (ed.) pp. 961-1010. SSSA Book Series no. 5. SSSA-ASA, Madison, WI.

Nishiyama K, Kimura T, Isono Y, Inoue Y 2011: Color measurements of rocks and soils using colorimeters. Jour. Japan Soc. Eng. Geol., 52, $62-71$ (in Japanese).

Parfitt RL, Childs CW 1988: Estimation of forms of Fe and Al: a review, and analysis of contrasting soils by dissolution and Mossbauer methods. Aust. J. Soil Res., 26, 121-144.

Post DF, Levine SJ, Bryant RB, Mays MD, Batchily AK, Escadafal R, Huete AR 1993: Correlations between field and laboratory measurements of soil color. In Soil color. JM Bigham and EJ Ciolkosz (ed.) pp. 35-50. SSSA. Spec. Publ. 31. SSSA, Madison, WI.

Sano S, Yanai J, Kosaki T 2004: Evaluation of soil nitrogen status in Japanese agricultural lands with reference to land use and soil types. Soil Sci. Plant Nutr., 50, 501-510.

Sawada K, Wakimoto T, Hata N, Taguchi S, Tanaka S, Tafu M, Kuramitz H 2013: The evaluation of forest fire severity and effect on soil organic matter based on the $L^{*}, a^{*}, b^{*}$ color reading system. Anal. Methods, 5, 2660-2665.

Scheinost AC, Schwertmann U 1999: Color identification of iron oxides and hydroxysulfates: Use and limitations. Soil Sci. Soc. Am. J., 63, 1463-1471.

Schulze DG, Nagal JL, Van Scoyoc GE, Henderson TL, Baumgardner MF, Stott DE 1993: Significance of organic matter in determining soil colors. In Soil color. JM Bigham and EJ Ciolkosz (ed.) pp. 71-90. SSSA. Spec. Publ. 31. SSSA, Madison, WI.

Schwertmann U 1993: Relations between iron oxides, soil color, and soil formation. In Soil color. JM Bigham and EJ Ciolkosz (ed.) pp. 51-70. SSSA. Spec. Publ. 31. SSSA, Madison, WI.

Soil Survey Staff 2010: Keys to Soil Taxonomy, Eleventh Edition, p.338, USDA-NRCS, Washington 
Torrent J, Barrón V 1993: Laboratory measurement of soil color: Theory and practice. In Soil color. JM Bigham and EJ Ciolkosz (ed.) pp. 21-34. SSSA. Spec. Publ. 31. SSSA, Madison, WI.

Viscarra Rossel RA, Minasny B, Roudier P, McBratney AB 2006: Colour space models for soil science. Geoderma, 133, 320-337.

Viscarra Rossel RA, Fouad Y, Walter C 2008: Using a digital camera to measure soil organic carbon and iron contents. Biosystems Engineering, 100, 149-159.

Wills SA, Burras CL, Sandor JA 2007: Prediction of soil organic carbon content using field and laboratory measurements of soil color. Soil Sci. Soc. Am. J., 71, 380-388.

Yamaki A, Anzai T 2001: An estimation of cation exchange capacity on upland soils in Chiba Prefecture. Jpn. J. Soil Sci. Plant Nutr., 72, 679-683 (in Japanese).

Yanai J, Lee CK, Kaho T, Iida M, Matsui T, Umeda M, Kosaki T 2001: Geostatistical analysis of soil chemical properties and rice yield in a paddy field and application to the analysis of yield-determining factors. Soil Sci. Plant Nutr., 47, 291-301.

Yanai J, Okada T, Yamada H 2012: Elemental composition of agricultural soils in Japan in relation to soil type, land use and region. Soil Sci. Plant Nutr., 58, 1-10.

Yang S, Fang X, Li J, An Z, Chen S, Fukusawa H 2001: Transformation functions of soil color and climate. Science in China (Series D), 44, 218-226. 


\section{Captions of Tables and Figures}

Table 1: Descriptive statistics of soil color parameters and their related properties.

Table 2: Correlation matrix among the soil color parameters and their related properties (field-scale samples).

Table 3: Correlation matrix among the soil color parameters and their related properties (national-scale samples).

Figure 1: A picture showing measurement of a soil sample packed in a plastic cell with SPAD-503.

Figure 2: Relationship between the two measurements of the $\mathrm{L}^{*}$ value (lightness) of the same sample through different side of a cell. The $\mathrm{L}^{*}$ values after three treatments were compared: 2-mm sieved sample (top), about $5 \mathrm{~g}$ of 2-mm sieved sample finely ground for an unspecified period (middle), and $2.00 \mathrm{~g}$ of 2-mm sieved sample finely ground for 3 minutes (bottom).

Figure 3: Relationship between soil color parameters and their related properties (field-scale samples).

Figure 4: Relationship between soil color parameters and their related properties (national-scale samples). Symbols in the figure represent paddy soils $(\bigcirc)$, Andosols $(\mathbf{O})$ and other soils $(\times)$.

Figure 5: Relationship between Munsell value and organic matter content (national-scale samples). Symbols in the figure represent paddy soils $(\bigcirc)$, Andosols $(\mathbf{O})$ and other soils $(\times)$. The broken line in the figure $(y=-3.5 x+17)$ indicates an approximate guide used in Japan for estimating organic matter level in Andosols in the field using a wet sample and Munsell color charts (Japanese Society of Pedology 1997). 
Table 1 Descriptive statistics of soil color parameters and their related properties.

\begin{tabular}{|c|c|c|c|c|c|c|c|c|c|}
\hline & & $\mathrm{L}^{*}$ & $a^{*}$ & $b^{*}$ & $\mathrm{C}^{*}$ & $\mathrm{~h}$ & $\begin{array}{l}\text { Total C } \\
\left(\mathrm{g} \mathrm{kg}^{-1}\right)\end{array}$ & $\begin{array}{l}\text { Total N } \\
\left(\mathrm{g} \mathrm{kg}^{-1}\right)\end{array}$ & $\begin{array}{c}\mathrm{Fe}_{\mathrm{o}} \\
\left(\mathrm{g} \mathrm{kg}^{-1}\right)\end{array}$ \\
\hline Field-scale & Average & 56.9 & 3.6 & 12.1 & 12.6 & 73.4 & 30.9 & 2.9 & 5.3 \\
\hline \multirow[t]{3}{*}{ (A single field, $n=100$ ) } & Maximum & 59.2 & 3.9 & 13.2 & 13.6 & 74.7 & 43.2 & 4.2 & 7.0 \\
\hline & Minimum & 54.8 & 3.3 & 11.2 & 11.7 & 72.0 & 21.8 & 2.1 & 4.0 \\
\hline & $\mathrm{CV}(\%)$ & 1.5 & 4.2 & 4.4 & 4.3 & 0.7 & 15.2 & 14.0 & 13.0 \\
\hline National-scale & Average & 54.5 & 5.5 & 15.8 & 16.8 & 70.8 & 33.0 & 2.6 & 9.5 \\
\hline \multirow[t]{3}{*}{ (All soils, $n=147$ ) } & Maximum & 68.6 & 17.7 & 36.5 & 40.5 & 79.9 & 109.2 & 7.8 & 33.5 \\
\hline & Minimum & 32.1 & 1.7 & 8.0 & 8.1 & 60.4 & 1.8 & 0.4 & 0.6 \\
\hline & CV (\%) & 14.6 & 37.2 & 31.2 & 31.3 & 5.2 & 67.0 & 54.6 & 64.5 \\
\hline National-scale & Average & 58.5 & 4.7 & 15.4 & 16.2 & 73.2 & 23.8 & 2.1 & 7.8 \\
\hline \multirow[t]{3}{*}{ (Paddy soils, $n=65$ ) } & Maximum & 66.0 & 7.9 & 23.6 & 24.8 & 79.9 & 44.9 & 4.2 & 19.2 \\
\hline & Minimum & 47.2 & 1.7 & 8.0 & 8.1 & 66.7 & 8.9 & 0.9 & 1.8 \\
\hline & CV (\%) & 5.9 & 28.0 & 21.3 & 21.5 & 3.5 & 35.1 & 33.5 & 50.5 \\
\hline National-scale & Average & 45.7 & 5.7 & 13.8 & 15.0 & 67.2 & 56.0 & 4.0 & 14.4 \\
\hline \multirow[t]{3}{*}{ (Andosols, $n=43$ ) } & Maximum & 57.0 & 9.4 & 23.6 & 25.0 & 71.9 & 109.2 & 7.8 & 33.5 \\
\hline & Minimum & 32.1 & 3.9 & 8.4 & 9.4 & 60.4 & 23.5 & 1.8 & 2.8 \\
\hline & CV (\%) & 14.1 & 20.4 & 27.6 & 26.3 & 4.0 & 41.1 & 35.7 & 52.4 \\
\hline National-scale & Average & 57.4 & 6.6 & 18.8 & 19.9 & 70.6 & 23.1 & 1.9 & 7.0 \\
\hline \multirow[t]{3}{*}{ (Other soils, $n=39$ ) } & Maximum & 68.6 & 17.7 & 36.5 & 40.5 & 76.9 & 74.3 & 5.0 & 18.2 \\
\hline & Minimum & 41.0 & 3.3 & 8.5 & 9.3 & 64.2 & 1.8 & 0.4 & 0.6 \\
\hline & CV (\%) & 12.8 & 45.9 & 36.1 & 36.9 & 4.2 & 78.9 & 62.5 & 57.5 \\
\hline
\end{tabular}


Table 2 Correlation matrix among the soil color parameters and their related properties (Field-scale samples)

\begin{tabular}{|c|c|c|c|c|c|c|c|c|}
\hline & $\mathrm{L}^{*}$ & $a^{*}$ & $b^{*}$ & $\mathrm{C}^{*}$ & $\mathrm{~h}$ & Total C & Total N & $\mathrm{Fe}_{\circ}$ \\
\hline $\mathrm{L}^{*}$ & 1.00 & & & & & & & \\
\hline$a^{*}$ & 0.10 & 1.00 & & & & & & \\
\hline$b^{*}$ & $\underline{0.70}$ & $\underline{0.70}$ & 1.00 & & & & & \\
\hline $\mathrm{C}^{*}$ & $\underline{0.67}$ & $\underline{0.74}$ & 1.00 & 1.00 & & & & \\
\hline $\mathrm{h}$ & $\underline{0.78}$ & -0.36 & $\underline{0.41}$ & $\underline{0.36}$ & 1.00 & & & \\
\hline Total C & -0.43 & 0.12 & -0.28 & -0.26 & -0.52 & 1.00 & & \\
\hline Total N & -0.51 & 0.07 & -0.38 & -0.35 & -0.60 & $\underline{0.93}$ & 1.00 & \\
\hline $\mathrm{Fe}_{\mathrm{o}}$ & $\underline{0.51}$ & $\underline{0.56}$ & $\underline{0.77}$ & $\underline{0.77}$ & $\underline{0.28}$ & 0.04 & -0.02 & 1.00 \\
\hline
\end{tabular}

Values significant at $1 \%$ and $5 \%$ level are 0.26 and 0.20 , respectively.

Underlined values represent statistical significance at $1 \%$. 
Table 3 Correlation matrix among the soil color parameters and their related properties (National-scale samples)

\begin{tabular}{|c|c|c|c|c|c|c|c|c|}
\hline & $\mathrm{L}^{*}$ & $a^{*}$ & $b^{*}$ & $\mathrm{C}^{*}$ & $\mathrm{~h}$ & Total C & Total $\mathrm{N}$ & $\mathrm{Fe}_{\mathrm{o}}$ \\
\hline $\mathrm{L}^{*}$ & 1.00 & & & & & & & \\
\hline$a^{*}$ & 0.19 & 1.00 & & & & & & \\
\hline$b^{*}$ & 0.59 & 0.85 & 1.00 & & & & & \\
\hline $\mathrm{C}^{*}$ & $\underline{0.55}$ & 0.89 & 1.00 & 1.00 & & & & \\
\hline h & 0.75 & -0.37 & 0.14 & 0.07 & 1.00 & & & \\
\hline Total C & -0.83 & -0.15 & -0.49 & -0.45 & -0.65 & 1.00 & & \\
\hline Total N & -0.77 & -0.15 & -0.45 & -0.42 & -0.58 & 0.97 & 1.00 & \\
\hline $\mathrm{Fe}_{\mathrm{o}}$ & -0.43 & 0.18 & 0.06 & 0.08 & -0.31 & 0.53 & 0.56 & 1.00 \\
\hline
\end{tabular}

Values significant at $1 \%$ and $5 \%$ level are 0.21 and 0.16 , respectively.

Underlined values represent statistical significance at $1 \%$. 


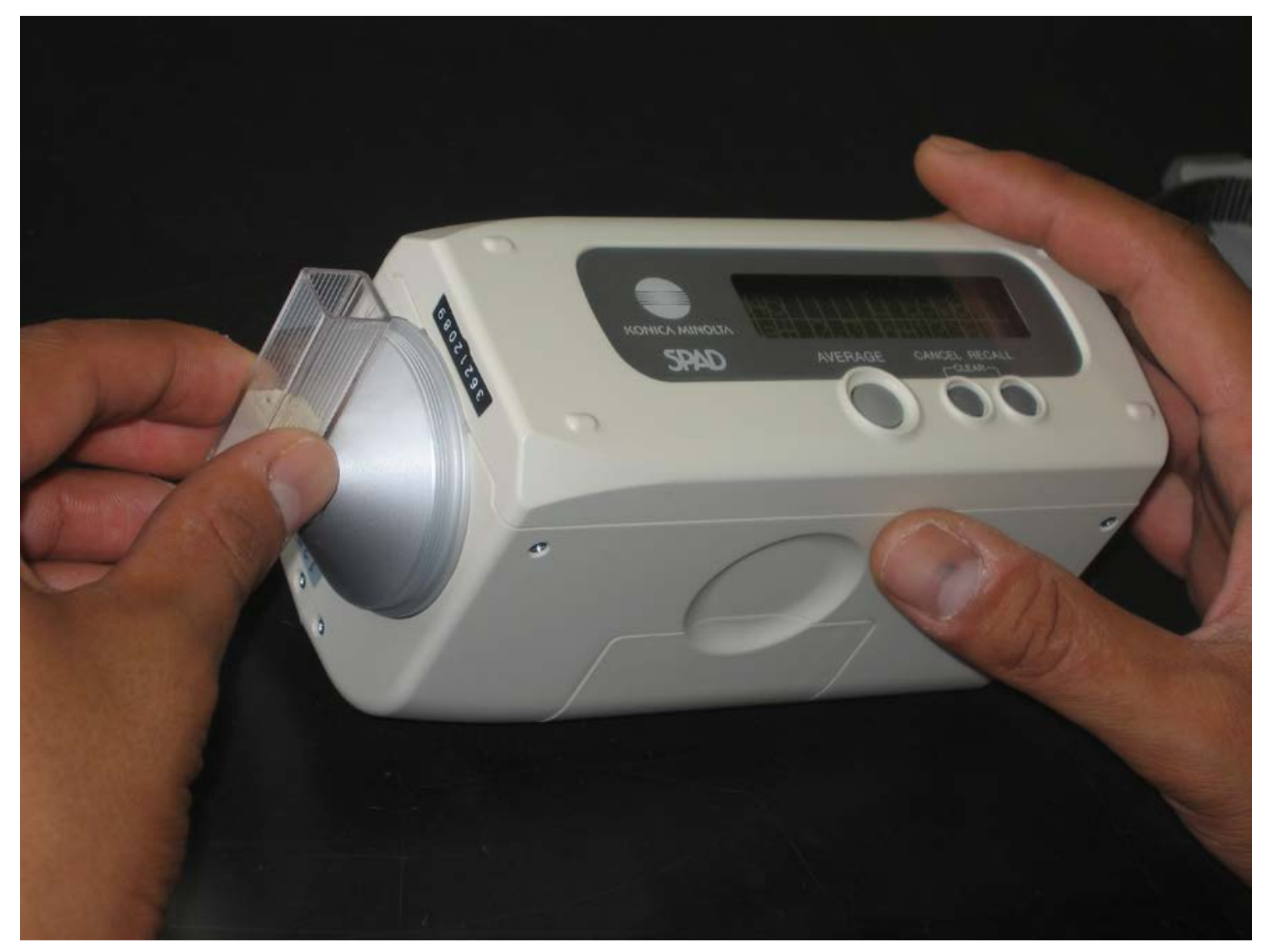

Figure 1: A picture showing measurement of a soil sample packed in a plastic cell with SPAD-503. 


\section{2-mm sieved sample}

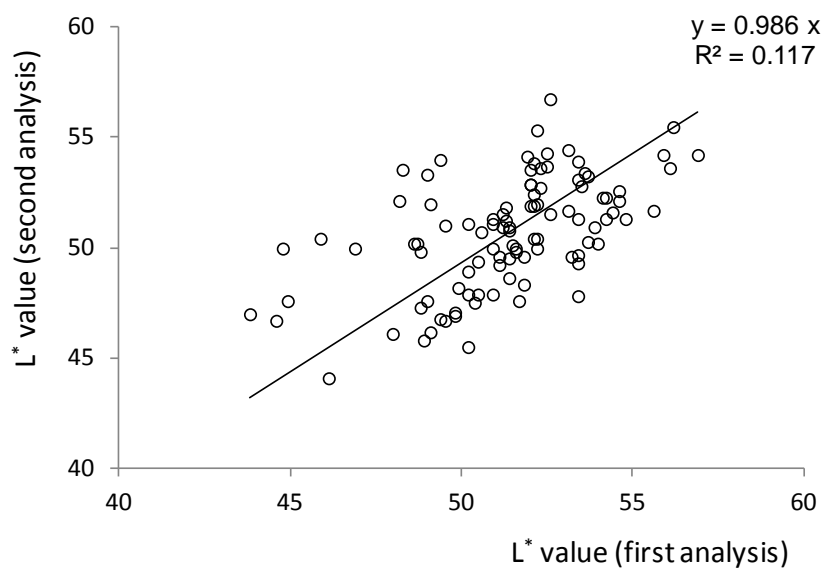

Finely ground sample (unspecified)

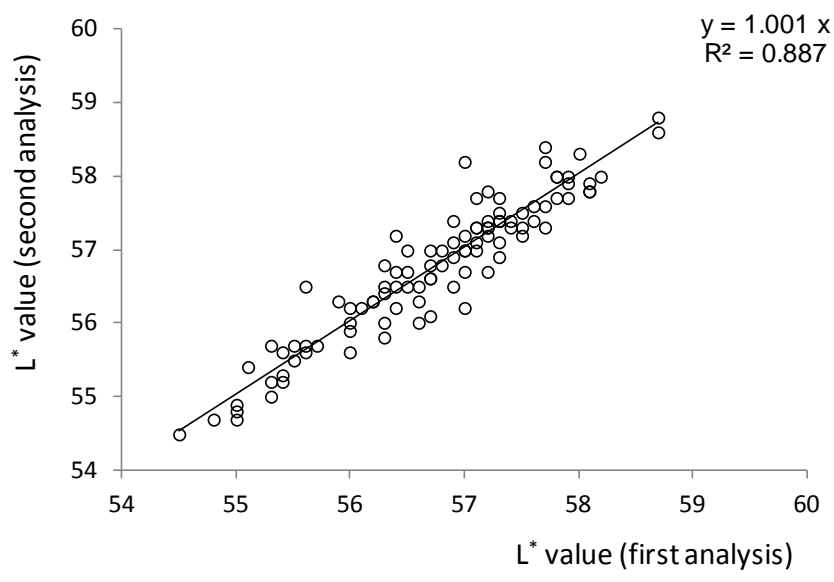

Finely ground sample ( $2 \mathrm{~g}$ soil for $3 \mathrm{~min}$ )

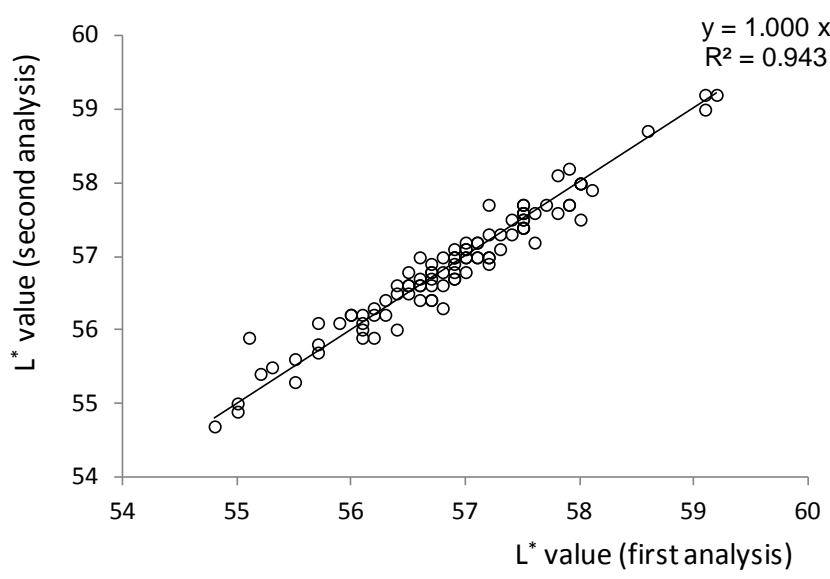

Figure 2: Relationship between the two measurements of the $L^{*}$ value (lightness) of the same sample through different side of a cell. The $L^{*}$ values after three treatments were compared: 2 -mm sieved sample (top), about $5 \mathrm{~g}$ of 2-mm sieved sample finely ground for an unspecified period (middle), and $2.00 \mathrm{~g}$ of $2-\mathrm{mm}$ sieved sample finely ground for 3 minutes (bottom). 

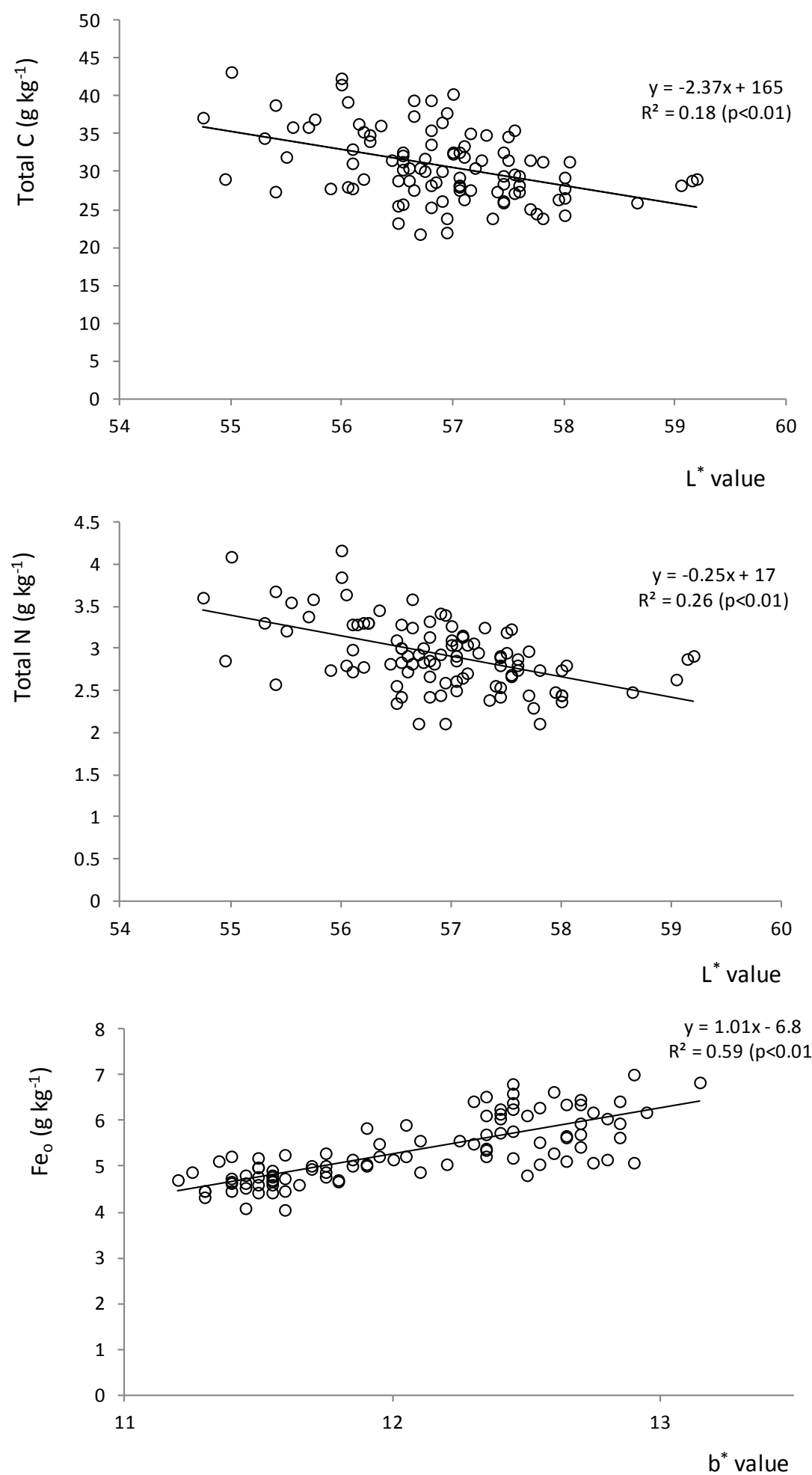

Figure 3: Relationship between soil color parameters and their related properties (fieldscale samples). 

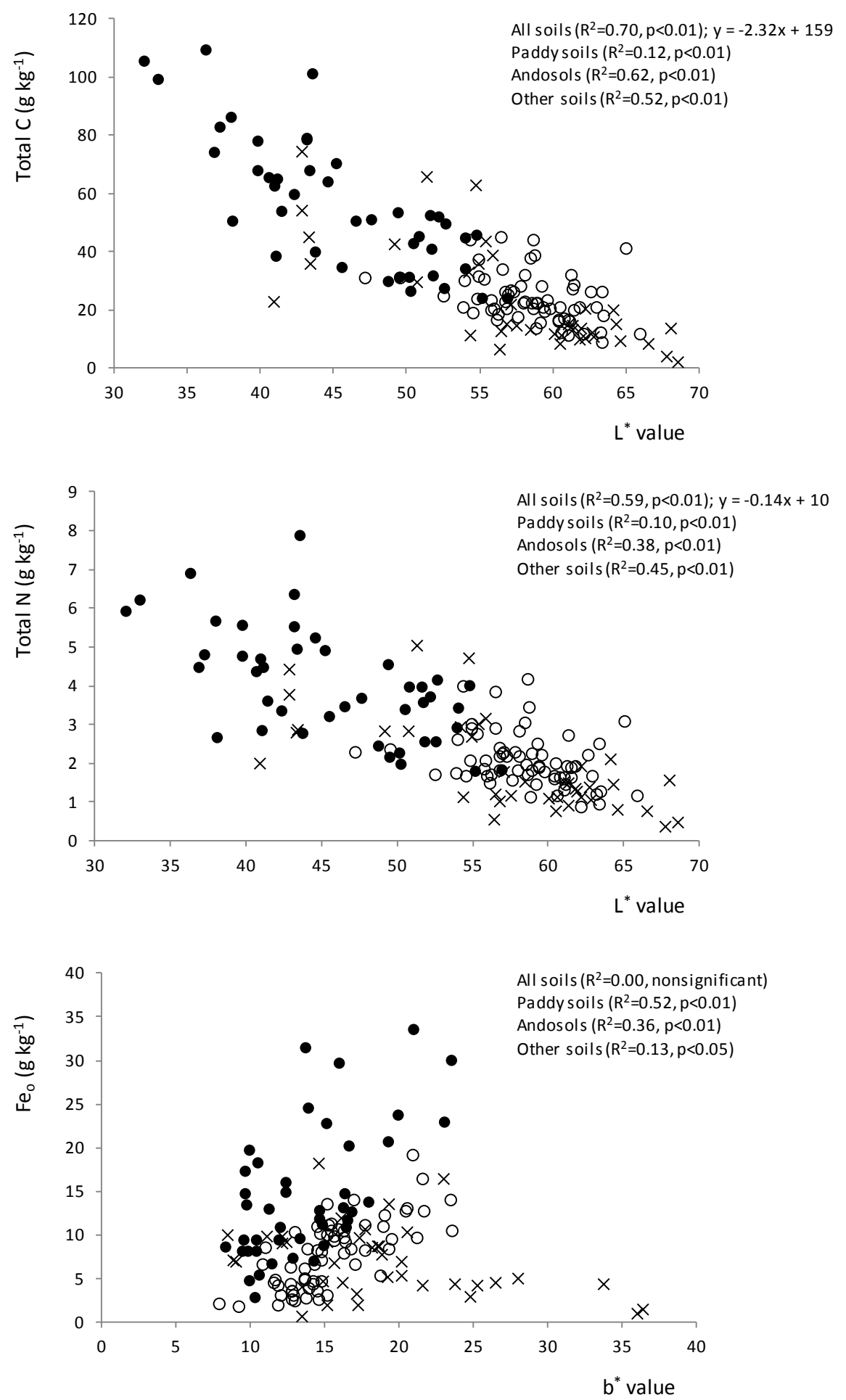

Figure 4: Relationship between soil color parameters and their related properties (national-scale samples). Symbols in the figure represent paddy soils $(O)$, Andosols $(O)$ and other soils $(X)$. 


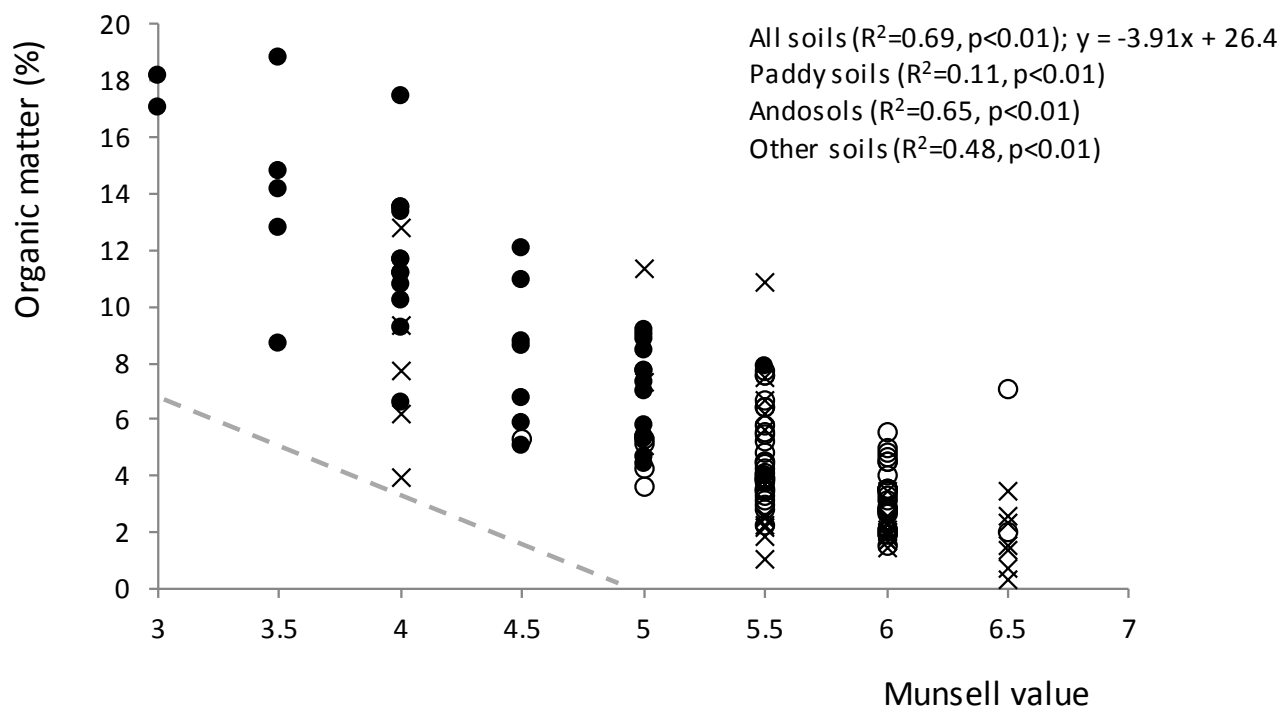

Figure 5: Relationship between Munsellvalue and organic matter content (national-scale samples). Symbols in the figure represent paddy soils $(O)$, Andosols $(O)$ and other soils $(x)$. The broken line in the figure $(y=-3.5 x+17)$ indicates an approximate guide used in Japan for estimating organic matter level in Andosols in the field using a wet sample and Munsell color charts (Japanese Society of Pedology 1997). 